\title{
Tatiana Panfilova
}

(Lwów)

\section{CIVIL SOCIETY STRUCTURES IN UKRAINE:}

FORMATION AND DEVELOPMENT FROM

\section{THE LATTER HALF OF $16^{\mathrm{TH}}$ TO $19^{\mathrm{TH}}$ CENTURY}

\section{Abstract}

Based on the sources and critical consideration of historiography of the problem, the author defines regularities and specific features of the formation of structures of Ukrainian civil society, as a factor which bolstered Ukrainian national idea.

\section{Key words}

Western Ukraine, civil society, Galichyna, Ukrainian national idea 
Depending on the time and conditions of the emergence, consolidation and thus the level of social, economic and national political maturity of society at a certain stage of its development, analysts seek to define a the essence of civil society. It reflects a set of relations which are not state-dependent and political but reflect local government activity, a variety of economic, social, political, national, cultural and religious associations that operate relatively autonomously from the state and are mostly outside its regulatory control.

However, civil society and the state should not be opposed on the grounds that they occur in different eras or on the basis of the fact that one of these two entities is the primary and crucial one. The organization of society and management of social processes are actually never "carried out only" by the state "or only by civil means, as they are mixed. Different epochs are distinguished not by the fact that there is state in one era and a society in other, but the fact that in social life the first or the second element is dominant"1.

Based on these conceptual foundations we should be able to trace patterns and certain characteristics of the origins, formation and operation of civil society in Ukraine in the second half of $16^{\text {th }}-19^{\text {th }}$ century.

The formation of civil society is a long and complex historical process. It emerged in Ukraine in the second half of 16th and the early $17^{\text {th }}$ century, after the collapse of the Kyiv State and Galicia-Volhynia Princedom, when almost all of its ethnic territory became a part of the Polish-Lithuanian Commonwealth. During this period, due to increased social, national and religious oppression, peasants and townspeople from the Dnieper Ukraine and later from Galicia and Western Volhynia and Western Podolia fled and settled in the south of Ukraine, in the so-called Wild Fields. They mastered these lands, engaged in agriculture, crafts and trade, and at the same time mastered the art of war, protecting the land from predatory attacks of Crimean Tatars and Polish magnates. As a result, a separate social group emerged - the Cossacks - who established on reclaimed land their order against the feudal system, social, national and religious tyranny of Polish occupation authorities. Military and administrative structures of the Zaporizhian Sich were based on self-governing communities, and were, in fact, the Cossack state government. Well-known historians, Valery Smoliy and Valery Stepankov, argued:

\footnotetext{
${ }^{1}$ V. Knyazev, F. Kanak, Derzhava i gromadyanske suspilstvo: evotutsia stosunkiv ta yih osmyslennya, [in:] Formuvannya gromadyanskogo suspilstva v Ukraini: stan, problemy, perspectyvy: Collection of scientific works of the Ukrainian Academy of Public Administration Under the President of Ukraine, Kyiv 2001, pp. 16-17.
} 
in the crucible of the improvised firearm and plough there emerged a "cumulative historical person", a social figure different from a peasant, endowed with will, intelligence, ability not only to accept but also to generate ideas and take active initiative, "thus assuming" a historic mission of the national spokesman of the Ukrainian people ${ }^{2}$.

In the late $16^{\text {th }}$ and the early $17^{\text {th }}$ century, social, political, national and cultural role of the Cossacks of the Zaporizhian Sich increased. This stimulated the formation of the national idea, the backbone of which was to restore the independence of Ukraine and reinforce the values of civil society. Valery Shevchuk believes that:

in the $16^{\text {th }}$ century Ukrainians definitely transformed from population into a nation that became the bearer of the national idea. It stipulated not only liberation from the foreign yoke, but also the formation of the society in the form of principality or Cossack state, the struggle for which began through armed and ideological effort (through literature and socio-political writings) fight ${ }^{3}$.

Contemporary domestic elite have consistently protected national cultural and religious rights of the Ukrainian people and its struggle for the restoration of state independence. Cossacks have been acknowledged as native bearers of tradition. In 1621, Kyiv Orthodox bishops proclaimed that:

Zaporizhian army is a glorious tribe of Ruthenian people, who came from seed of Yafet, who fought with Greek kingdom in the Black Sea and on Under Volodymyr, the Prince of Ruthenia, they fought in Greece, Macedonia. It is their ancestors who together with Volodymyr were baptized and accepted the Christian faith from the Church of Constantinople. Ukraine is very proud of that army ${ }^{4}$.

However, Ukrainian elite were aware that national religious liberation and creation of an independent state is the historic mission of the Cossacks of the Zaporizhian Army as well as all social strata. Because of this, education acquired particular importance as a factor in the restoration of historical memory and the establishment of a national idea, thus attracting the public to the national liberation movement.

${ }^{2}$ V. Smoliy, V. Stepankov, Ukrainska natsionalna revolutsia 17 st. (1648-1676), Kyiv 2009, pp. $49-50$.

${ }^{3}$ V. Shevchuk, Nacionalna idea v Ukraini, zokrema nacionalno-vyzvolna, ta yiyi podvyzhnyky, Kyiv 2007, pp. 45-46.

${ }^{4}$ Y. Dzyra, Persyi passport kozatstva. Naydavnishyi reestr Nyzovogo viyska. 1581, Literaturna Ukraina 13, 1991. 
The essential role in organising of cultural, educational and religious institutions belonged to brotherhoods, which founded a network of schools run by churches, monasteries and town councils, to sustain the principles of common good, common agreement and thus to form a citizen who is a patriot, and a fighter for a better future of theircountry. At the same time, secondary and higher education establishments were formed thanks to the efforts of patriotic gentry, in particular the Ostrog Academy and Kyiv-Mohyla Academy, which played extremely important role in the formation of the Ukrainian elites, including Cossack leaders and leaders of the national liberation movement ${ }^{5}$.

All educational, cultural and religious associations were operating on the principles of self-government. They were elements of the structure of civil society structures and were relatively or completely independent of the government. We should not forget that, having adopted the Magdeburg Rights, the city councils of Ukraine were also operating on the principles of self-government. The privileges of Casimir III concerning granting Magdeburg Rights to L'viv stated: "We free the city and its inhabitants from all jurisdictions of castellans, magistrates, judges, and of the authorities of anybody..."6.

Ideological means of consolidating Ukrainian society included Orthodox religion and its religious institutions, which also acted on the basis of selfgovernment. According to Vyacheslav Lypynski, in the early $17^{\text {th }}$ century the Orthodox Church in Ukraine finally gained what it lacked namely a religious upbringing, education, and disciplined organization, "the ability to go without dependence on secular authority and political support from this power" that is "neither from the Moscow Orthodox tsar, nor the grace of the Polish king". Thus "public authority of the church was the basis of political and public revival of the nation".

Vyacheslav Lypynski came to the conclusion that only through will "of our spiritual leaders of the nation in those times" is it possible to explain a miracle that happened in Ukraine with the help of Bohdan Khmelnytsky and only under the spiritual influence of the authoritative Ukrainian church. This led to the unification of state, national territories and religion composed of different elements ${ }^{7}$.

\footnotetext{
${ }^{5}$ V. Shevchuk, Nacionalna idea v Ukraini, p. 75.

${ }^{6}$ Pryvileji mista Lvova: 16-17 st., Lviv 1998, pp. 29-30.

${ }^{7}$ V. Lypynskyy, Religia i cerkva v istorii Ukrainy, New York 1956, pp. 33-34.
} 
A good example of this was the fact that thousands of Cossacks and peasants joined the uprising in the late $16^{\text {th }}$ and in the early $17^{\text {th }}$ century led by Kryshtof Kosynsky, Severin Nalyvaiko and Gregory Loboda, Karp Skydan, Jakov Ostryanin and Dmitry Gunia. On the territories liberated from Polish magnates the rebels introduced Cossack system of government and created bodies of the Ruthenian state. In 1596, in a letter to King Sigismund III, Severin Nalyvayko formulated the program of a future state of the insurgent people: to define the Cossack area - Podilia and uninhabited area, to build a walled city - the capital of this state, to which Zaporizhian Sich would be subject as well. In 1637, the leader of the Cossack and peasant rebels, Carp Skydan named himself a "guardian of the whole Ukraine" and called to defend "our Russian people and faith of our age-old Greek", against his enemies - Poles who want to "kill Cossacks" and to enslave "royal subjects,

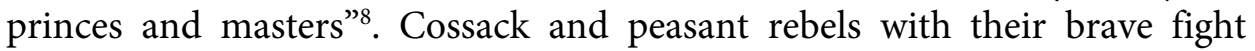
showed high patriotism and civic responsibility for the future of their country. In 1625, Polish King Sigismund III admitted that "having forgotten their faith and allegiance, Cossacks considered themselves as a separate Commonwealth".

Thus, at the end of $16^{\text {th }}$ and in early $17^{\text {th }}$ century as a result of Cossack activities, the work of self-governing institutions, brotherhoods, cultural and educational associations, creative intellectuals and political elite as well as thanks to the increasing public and organisational authority of the Orthodox Church, when "Kyiv metropolitan became the father of the nation and Hetmanat", brought about the consolidation of the Ukrainian people. It was in those circumstances that Ukrainian civil society arose and formed, as an important factor in the implementation of the national idea and the willingness and ability of people to create and build their own state.

During the revolutionary war in 1648-1676, state, social and political processes in Ukraine accelerated and deepened dramatically, acquiring massive character. This was due to many factors, the most important of which included the creation of a nation-state, its socio-economic, cultural and church activities, and the increasing role of self-governing bodies and public associations. In general, the Cossack state was revived and became not a body of monarchist-feudal power but of the Ukrainian people who kept to the traditions of the Cossack Army during the revolutionary war. Therefore the driving force of the national struggle and thus the main subject of state creation

\footnotetext{
${ }^{8}$ V. Shevchuk, Nacionalna idea v Ukraini, pp. 70-74.

${ }^{9}$ V. Smoliy, V. Stepankov, Ukrainska natsionalna revolutsia, pp. 49-50.
} 
was represented by its various social strata and groups and the national elite. In this regard, the formation and functioning of the Ukrainian civil society reflected the close interweaving of the activities of the Cossack state power with public self-governing bodies and associations.

From the very beginning, the Cossack state originated and evolved on the basis of activities of self-governing bodies and selectivity and therefore accountability of all elected bodies: from Hetman, colonel - to Captain. The role of the legislature in the Zaporizhian Sich was fulfilled by all Cossacks through the Cossacks' Council. The Cossacks elected the government, referred to as "Kish", as well and the chieftain-Hetman who represented the supreme executive power.

In the summer of 1648, after the first victorious battles with the Polish army at Zhovti Vody and Korsun the state program of Bohdan Khmelnytsky included: the establishment of the independent Cossack state with autonomous rights within Poland on the territory up to Bila Tserkva and Uman'; restoration of "ancient liberties"; abolishment of the magistrates and elders in cities, castles and royal possessions; submission of the Cossack Army to "only one king". In August and September 1648, the contours of the new Ukrainian state were outlined within the federal territory of the Polish-Lithuanian Commonwealth of Poland in Bratslav, Kyiv, Podolsk and Chernigov provinces with the same status as the Duchy of Lithuania. Finally, in late December 1648 and May 1649 Ukrainian political elite declared national independence of Ukrainian lands from the Commonwealth of Poland-Lithuania. In February 1649, Polish commissioners who negotiated with Bohdan Khmelnytsky reported to the King that "Hetman" is "not only the ruler of Cossacks but the ruler and the Prince of Ruthenian provinces, as he commanded to call himself"

During the solemn entry into the capital city of Kyiv, the great hetman solemnly declared determination to not only restore the Ukrainian state, but also to reunite all of its lands.

I shall free all the people of Ruthenia from Polish bondage. God revealed to me, that I am the ruler of Ruthenia. I have enough benefits, welfare and the profit in my principality up to Lviv, Holm and Halych. And when I stand at the bank of the Vistula I shall say to Poles: sit there and be quiet. There will be no trace of prince or magnate, but those who want eat bread with us should be obedient to Zaporizhia army ${ }^{11}$.

\footnotetext{
${ }^{10}$ Ibidem, pp. 240-242, 244-247.

${ }^{11}$ Y. Dzyra, Persyi passport kozatstva, p. 5.
} 
In other words, Bohdan Khmelnytsky sought to revive an integrated homeland "Grand Duchy of Ruthenia in its ethnic, cultural and geopolitical framework". An unknown author of a panegyric to the Hetman Bohdan Khmelnytsky and scribe Ivan Vyhovsky from all Ruthenian'-Ukrainian people testified that after three centuries Kyiv principality was revived in 1649:

From the time of Volodymyr's sons the Ruthenia has fallen But from the time of Bogdan Khmelnytsky It has risen on its feet ${ }^{12}$.

The national state of Bohdan Khmelnytsky retained mostly self-governing structure, but at the same time, he improved the Cossack administrative system, known among Ukrainian historians as "regimental-squadron" or "regimental-sotnia" system (basing on two main levels which form it - regiment and squadron). First, Khmelnytsky transformed the "kuren" arrangement (traditional administrative unit of Zaporizhian Sich, based on separate barracks which Zaporizhian Cossacks called "kuren") into "palancas" (administrative units that covered a certain territory of Zaporizhian Sich). And, in the early 1650s, he formed 16 regiments. Regiment as administrative structure concentrated all the power that hitherto belonged to Polish state structures. However, the power of the Hetman was reinforced as he represented the "collective will" of the Cossack Army. This act was motivated by the determination of Bogdan Khmelnitsky to bring actions of insurgent people, including the Cossack army, under his control, in order to successfully implement a strategic goal - "to free all the people of Rus' from Polish enslavement".

In this regard, Vyacheslav Lypynski made a conceptual conclusion. "In public and political life the Great Hetman was able to overcome Ukrainian anarchy. He was the only one who managed to organize Ukrainian material force to bring about the creation of a state"13. In "secret communiqués", anonymous author claimed that "bondage of Ukraine... puts all hopes to Bogdan Khmelnitsky" who "undoubtedly can release them from the citizenship of the Commonwealth of Poland" 14 .

Given the specific conditions of the formation and consolidation of national independence of Ukraine, the Zaporizhian Army, on the one hand, was the stronghold of the government, but on the other, was a part of self-

\footnotetext{
${ }^{12}$ Y. Dzyra, Persyi passport kozatstva.

${ }^{13}$ V. Lypynskyy, Religia i cerkva, p. 70.

${ }^{14}$ V. Smoliy, V. Stepankov, Ukrainska natsionalna revolutsia, pp. 249-252.
} 
governing community structures. During the revolutionary war the number of Cossack troops steadily increased, fed by the peasants and burghers and reached hundreds of thousands on a greater part of the ethnic territory of Ukraine. This increased the value of Cossacks in the formation and consolidation of the civil society, not only as part of the government but also in social structures, including city councils, as well as the cultural, educational and religious associations, especially in fraternities.

Hence the participation of the peasantry in these processes has been increased. The main impetus of the associated social activity was to implement the Cossack ideal and spread Cossack viewpoint "throughout Ukraine" and thus to get rid of the tyranny of feudal magnate. Having abolished in 1652 the feudal form of land ownership and the various duties, the Hetman government legitimized the conquests of the peasantry, which contributed to the strengthening of independent farmers, free landowners, builders of civil society. It may be noted that the peasants of France won the status of individual liberty and free farmland ownership only half a century later ${ }^{15}$.

The main role in the consolidation of Ukrainian society as part of the national liberation movements belonged, according to Vyacheslav Lypynski, to the Orthodox clergy and intellectuals of that time, who recognized the secular power of the hetman as a spiritual power of the people. The spiritual power created by the moral authority of the strong Ukrainian state, ultimately, engendered compliance of "the most culturally and politically the most valuable national conservative elements which are inherent, cannot exist without such a respected and strong power, but in an atmosphere of "common, equal and direct fight"16.

It is well known that in December 1648 Bohdan Khmelnytsky led his army to Kyiv, the capital of Ukraine. He was hailed as the Ukrainian Moses, the liberator of the Fatherland "from slavery". Subsequently, following meetings and conversations with the Patriarch of Jerusalem Pais and the Kyiv clergy a rite of passage was held for hetman Bohdan Khmelnytsky, thus legitimizing his powers of a hetman "over all the territory that was controlled by the Cossacks"17.

An important factor in the preservation of state as well as social and cultural achievements of the Ukrainian people during the struggle for national liberation was the problem of recognition and legitimization of Ukraine as an

\footnotetext{
${ }^{15}$ Ibidem, pp. 58-59.

${ }^{16}$ V. Lypynskyy, Religia i cerkva, pp. 70-71.

${ }^{17}$ V. Smoliy, V. Stepankov, Ukrainska natsionalna revolutsia, pp. 246-247.
} 
independent state with a republican the socio-political system by Central and Eastern Europe. In the Middle Ages, states emerged and operated on the basis of dynastic continuity of the monarchy and the rule of feudal relations. In the $17^{\text {th }}$ century, after Kyiv and Galicia-Volhynia state had been absent on international arena for several hundred years,, Ukraine had not lost only a princely dynastic tradition, but also the state-legacy of Kyiv Ruthenia and Galicia-Volhynia principality. Indeed, in Europe, the heirs of these lands were considered to belong to the Moscow Ruthenia and the Polish-Lithuanian Commonwealth.

In these circumstances to legitimize the Cossack state and to recognize it as an heir to Kyiv Ruthenia was extremely difficult. Therefore Cossack officers pursued two goals to legitimize Ukraine as a state. The first was to restore or to establish a new hetman royal dynasty. The idea of dynasty was accepted by hetman Bohdan Khmelnytsky who handed over the Hetman's mace to his son Yuri. But the majority of the Cossack officers did not support this initiative. So for decades hetmans, or in general Cossack elites, sought to acquire poly-vassalage as a part of one of the neighbouring feudal monarchical states ${ }^{18}$.

In search of the monarch, as overlord - the guarantors of Ukraine's statehood, hetmans negotiated with rulers of the Commonwealth of PolandLithuania, Muscovy, the Ottoman Empire and the Kingdom of Sweden. During the lengthy negotiations Hetman's administration tried to outline first the legal principles governing the entry of a monarch protector into state, and secondly - ensure the protection of social, economic, cultural, national, and religious achievements of the Ukrainian civil society.

Let us analyze this situation on the example of Ukrainian-Moscow agreements. On October $1^{\text {st }}, 1653$, the "Zemsky Sobor" in Moscow decided to take Ukraine "under the high hand of the king for the Orthodox faith", while in early January 1654 Pereyaslav, which was the capital of the Cossack state, saw the arrival of Moscow embassy to negotiate an alliance. It should be noted that the final agreement was not signed in Pereyaslav but in Moscow in March 1654, based on the so-called "March articles" prepared by Bohdan Khmelnytsky for the Ukrainian delegation to Moscow. According to the agreement, the tsar guaranteed Ukrainian state the following rights: Hetman and higher officers are elected by board, Ukrainian administration and judi-

\footnotetext{
${ }^{18}$ T. Chuhlib, Secrety ukrainskogo polivasalitetu: Khmelnytskyy - Doroshenko - Mazepa, Kyiv 2011, pp. 49-50.
} 
ciary are not subject to Muscovy; all taxes are collected by Ukrainians, Cossacks will consist of 60,000 units; the ancient division of social strata is preserved: Cossack, Gentry, philistines and spiritual people. Each stratum retained its own rights. Ukraine has the right to negotiate with other countries except the Polish-Lithuania Commonwealth of Poland and Crimean Khanate. Ukrainians recognized such rights of the tsar: to hold a governor with the garrison in Kyiv; Hetman was to inform the tsar about foreign embassies, and elections of a new Hetman. Tsar approved the rights of all strata by his letters ${ }^{19}$.

We may state that from a formal point of view this agreement seems to reflect fairly well the high level of common views of the parties regarding the union of the two countries. In fact, the crux of the problem lay elsewhere: each party understood the political nature recorded in these contracts differently. The Ukrainian side recognized the protection of the tsar, and resigned to the relative nominal vassalage which however legally meant that Ukrainian state severed its ties with the Polish-Lithuania Commonwealth and provided legal recognition of its sovereignty and the path to unification of Ukrainian lands within the united states, while the Russian side understood it as an act of incorporation of the Cossack country into their possessions, as the implementation of imperial policy "gathering of lands around Moscow"20, that is as an incorporation of Ukraine into the Muscovite state.

In addition, the implementation of the agreement of the two equal partners was obstructed by radically different public, political, social and economic systems in the Ukrainian and Moscow State. These elements were too incompatible in to form a single system. As already mentioned, in Ukraine there prevailed a republican form of government, an elected government and the principle of self-government, Magdeburg Law, a peasant was a free landowner, there were various cultural, educational and religious groups, including fraternities. Finally there was the state-independent Ukrainian Orthodox Church.

In Muscovy there was an absolutist monarchy, enslaved peasantry and no self-governing structures, the Orthodox Church was subordinated to the tsar and his administration. In general there were no citizens in the state but "loyal subjects of his Majesty", in other words slaves including even boyars and princes. At the time of Peter the Great the word "holop" was replaced by

\footnotetext{
${ }^{19}$ I. Krypyakevych, Istoria Ukrainy, Lviv 1990, pp. 178-179.

${ }^{20}$ V. Smoliy, V. Stepankov, Ukrainska natsionalna revolutsia, pp. 295.
} 
"slave" and the Empress Catherine II in 1786 reaffirmed the term "loyalist"21. Over the centuries, the tsarist government policy was to establish in Ukraine the same feudal monarchical power and lack of rights for all segments of the population, especially the peasantry.

Therefore, the Muscovite-Ukrainian agreements from 1654 and subsequent years should be evaluated not in terms of their content and certain declarations but in view of the consequences of their implementation. These outcomes were very tragic for the Ukrainian people because of the ultimate elimination of national independence, enslavement of the peasantry, destruction of civil society, Russification and ethnic discrimination etc. Actually, this gives grounds to assert that Pereyaslav-Moscow Agreement which submitted Ukraine to the Moscow tsar for 300 years not only threw the country back to the medieval era, but it stopped the further democratic development which occurred in the neighbouring Central European countries.

Also, we should not forget about the current problems of independent Ukraine when its centuries-long "protector", acting in the name of "Russian world" and "the single Orthodox people", uses gas and all other sorts of warfare trying to restore "single and indivisible Russia" and to eliminate state independence of Ukraine. This is also a direct consequence of being "under Moscow Monarch's high hand".

It is remarkable that already during the Moscow-Ukrainian negotiations in January 1654 in Pereyaslav, a part of Cossack officers and Orthodox clergy showed concern about the prospect of Ukraine as a vassal of Muscovy. Because of this, certain famous generals, such as Ivan Bohun, Ivan Sirko, Bratslav, Kropivianska, Poltava and Uman Cossack regiments, some cities, such as Chernobyl, and most importantly, the Orthodox clergy, headed by Metropolitan of Kyiv Silvestr Kosovyj, refused to swear allegiance to Moscow ${ }^{22}$.

Bohdan Khmelnytsky was also concerned about the fates of Ukraine, in that he "reluctantly accepted the position of the king's vassal and thought to succumb to the leadership of Moscow. He did not consider the obligations but went his own way by binding his power and the state"23. He continued to call himself a master "of the Ruthenian state". In 1655, the Hetman said to

\footnotetext{
${ }^{21}$ N. Polonska-Vasylenko, Istoria Ukrainy, II, Vid polovyny XVII storichcha do 1923 roku, München 1976, pp. 26-27.

${ }^{22}$ M.V. Lazarovych, Istoria Ukrainy, Kyiv 2008, pp. 161-163.

${ }^{23}$ I. Krypyakevych, Istoria Ukrainy, pp. 179.
} 
the Polish ambassador Stanislaw Lyubotskyi: "I became a master of all Ruthenia already and would not give it to anyone"24.

Bohdan Khmelnytsky consistently defended the sovereignty of the Cossack state and its social and political system and kept an eye on the activities of the Moscow tsar who did not comply with the agreements and considered Cossack state a part of his own. When Moscow signed the so-called Vilna truce with Poland without informing Khmelnytsky about it, the Hetman said that by such treacherous acts of Muscovite-Ukrainian the agreement is repealed. On October $2^{\text {nd }}, 1656$, the Cossack Council decided unanimously to defend Ukraine as they swore an oath to their land and not someone else's monarchs. A coalition of allied countries established by Khmelnytsky Ukraine, Sweden, Transylvania, Moldova, Volohiya and Brandenburg, had not only anti-Polish but also anti-Moscow character.

Military conflict with Moscow after the death of Bohdan Khmelnytsky (July $27^{\text {th }}, 1657$ ) approached even faster. The new Hetman, Ivan Vyhovsky, elected in October at the General Council of the Cossack, consistently continued to assert state independence of Ukraine and the consolidation of Cossacks. To that end, on September $16^{\text {th }}, 1658$, he signed with Poland the Gadiach agreement which provided for the creation of a federation of equal states - Poland, Lithuania and Ukraine. Titled as the Grand Duchy of Ruthenia, Ukraine had a legislature in the shape of the National Assembly and the executive branch of power - hetman who was elected by people, its own treasury and a coin, an army of 30,000 Cossacks (stationing of the PolishLithuanian troops on the territory of Ukraine was forbidden). The treaty further recognised the equality of the Roman Catholic and Orthodox religions, set up two universities, colleges and schools ${ }^{25}$. In general the Gadiach concord is an outstanding document concerning Ukrainian state in the Middle Ages.

In response to the signing of the Hadiach Treaty, the Moscow tsar Alexei Mikhailovich called Ivan Vyhovsky a traitor and declared war on Ukraine. In turn, the hetman sent a manifesto to all European countries, in which he accused Moscow of violating Pereyaslav agreement by signing the Vilna agreement with Poland, but also in support of the opposition to the hetman officers. On $28^{\text {th }}-29^{\text {th }}$ June, 1659, Cossacks led by Ivan Vyhovsky completely vanquished hundreds of thousands of Muscovite army near Konotop.

\footnotetext{
${ }^{24}$ N. Polonska-Vasylenko, Istoria Ukrainy, pp. 27.

${ }^{25}$ Istoria Ukrainy vid naydavnishyh chasiv do siogodennya. Zbirnyk dokumentiv I materialiv, Kyiv-Chernivtsi 2008, p. 231.
} 
It was a brilliant victory of democratic Ukrainian society over feudal monarchical Muscovy. It opened up excellent prospects for further development of Ukrainian state and its democratic structures. Unfortunately, this opportunity was wasted, because, as Vyacheslav Lypynski wrote, "In national history we often began to revive, but never finished this revival as we eliminated them every time before they had a possibility to finish their work" ${ }^{26}$. The same happened with Vyhovsky as many Cossack leaders were against him and wrote denunciations to the tsar in Moscow and to the Polish king. Consequently, Vyhovsky convened the General Council and surrendered his mace before it. In 1664, as a result of denunciation, Colonel Paul Teterya Vyhovsky was executed by the Polish authorities.

In 1667, without the participation of representatives from Ukraine, the Polish-Lithuanian Commonwealth and Muscovy signed the Andrusiv treaty, which legitimized the division of Ukraine between Poland and Moscow along the Dnieper river. This division was confirmed in 1686 by the Eternal Peace of Moscow and the Commonwealth. The ten-year struggle of Muscovy and Poland for Ukraine, which included different groups of Cossacks, not only marked the beginning of the ruin of Ukrainian statehood but also of its socio-economic and socio-political gains.

The subordination of the Kyiv Metropolis 1665 to the Patriarch of Moscow played a very negative role in this process. Indeed, for centuries the Orthodox Church was the spiritual basis of national self-preservation and the liberation struggle of the Ukrainian people for the restoration of their country. In Muscovy, the Orthodox Church was a mean of destruction of state-heritage and identity of the Ukrainian people, an important factor in building a unified and indivisible Muscovite empire - the prison of nations. In this regard, Vyacheslav Lypynski wrote that anarchy and moral decline of "ruling elite within the Cossack state under constant rebellion against those who ruled it, Ukraine turned back again into ruin"27.

In these complex internal and external circumstances, the patriotic faction of Cossack officers searched for ways and means to restore national independence and unity of Ukraine and preserve social and national cultural achievements of the Ukrainian nation. Again, as in the times of Bohdan Khmelnytsky and Ivan Vyhovsky, Cossacks continued to search for a reliable state, monarch, overlord of Ukraine. Nominations were the same - the Com-

\footnotetext{
${ }^{26}$ V. Lypynskyy, Religia i cerkva, pp. 65-66.

${ }^{27}$ Ibidem, pp. 35-36.
} 
monwealth of Poland, Muscovy, Swedish kingdom and the Ottoman Empire. Substantial effort to achieve an independent and unified Ukraine was made by Hetman Petro Doroshenko (1665-1676). He, though unsuccessfully, tried to solve this problem with all possible suzerains, including Turkey ${ }^{28}$.

In the early $18^{\text {th }}$ century, Ivan Mazepa took the most decisive steps for the revival of state independence of Ukraine and its territorial unity. Having made sure that the Muscovy would not allow the existence of Cossack autonomy, and most importantly - did not want the right-bank Ukraine to return under hetman government, Ivan Mazepa began negotiations with Charles XII of Sweden for "Ukrainian liberties equal to rights of Commonwealth of Poland and Lithuania". In the Ukrainian-Swedish agreement it was stated that: first- the King Charles XII "is obliged to defend Ukraine and align with it Cossacks lands..."; second - Everything on the former territory of Muscovy belongs to Ukrainian people; third - The Prince and all strata of Ukraine will keep their law and rights; fourth - "Ivan Mazepa is Ukrainian legitimate prince until his death" 29 .

In his address to the troops, Mazepa argued that this agreement will help to liberate Ukraine from Moscow's enslavement and tyranny and restore its sovereignty, that Ukraine will keep neutrality, and after the war would remain "in their natural previous rights and privileges as a free nation".

In the latest papers dated spring 1709, Mazepa argued for the alliance with King Charles XII of Sweden "in the name of our fatherland and people", and "its liberation from Moscow". The Hetman urged

If Bohdan Khmelnytsky could search for allies in the same way as Teterya and Doroshenko, why cannot we look for help and ask for the security from the Christian monarch August King of Sweden, for the liberation of our Motherland and all soldiers from Moscow yoke.... So we encourage and call upon you and in compassion to ourselves for our women and children, do not cast yourself into Moscow slavery... ${ }^{30}$.

In these papers Mazepa clearly outlined the essence of the agreement: strengthening national independence and the preservation of social, economic and national cultural achievements of Ukrainian people "for Ukraine to freely use its rights and liberties without any harm for eternal ages".

\footnotetext{
${ }^{28}$ V. Smoliy, V. Stepankov, Petro Doroshenko. Politychnyy portret, Kyiv 2011, pp. 136.

29 T. Chuhlib, Getmany i monarchy. Ukrainska derzhava v mizhnadordnych vidnosynach 1648-1714, Kyiv 2003, pp. 386-387.

${ }^{30}$ Ioann Mazepa, Vozhd viyska Zaporizkogo, oboh chasten Borystena, slavnogo ordena svyatogo Apostola Andrija, bologo orla Kavaler, Den’ 43-44, 12-13 March 2010.
} 
To what extent these freedoms were constitutionally guaranteed was clearly outlined Pylyp Orlyk in the "Pacts and Constitutions of Rights and Freedoms of the Zaporizhian Host", which is the first democratic constitution of medieval [Sn1]Europe. This constitution has in fact a generalized experience of Ukrainian Republican state, which was an integral part of civil society, its structure, self-governing bodies and associations. So Pylyp Orlyk primarily stated that Khmelnytsky with the Cossack Army took up the fight "just trying to protect the right of freedom and the Orthodox faith, which was strongly oppressed by Polish authorities...”. In this regard he described in details the development of the principles of Cossack democracy. It was about involvement of all segments of the population in the management of public affairs and that "during a war and in peace it was possible to gather private and public boards to discuss the common good of the Fatherland".

In addition, the Constitution declared the need for a public control aof state administration. Therefore, "always as Cossacks, and simple officers, especially colonels should be elected by voting and by free will", and after the elections, "one of them, assuming their post should make public oath of loyalty to the motherland, honest commitment to Hetman and duties of his service".

Particularly important role was attributed to constitutional rights and freedoms of citizens in order to keep their rights from being violated by officials and officers.

The Constitution protected cities, especially those that were subsequently transferred to the ownership of different bodies of spiritual and secular state.

In addition, it was assumed that under the Electoral Act a law should be passed "in order that the capital city Kyiv and other cities of Ukraine keep unaffected with all their laws and privileges, and this must be confirmed by the Hetman's power" 31 .

Unfortunately, after the tragic defeat of the national liberation struggle led by Ivan Mazepa and Pylyp Orlyk, elimination of the Zaporizhian Sich in 1775, and especially after the incorporation of Ukrainian lands into the Russian Empire and strengthening of the feudal monarchy and the enslavement of peasants in Ukraine the remains of the state and civil society were destroyed.

The gradual restoration of civil society in Ukraine began with the national revival in the first half of the $19^{\text {th }}$ century, which took place as part of the

${ }^{31}$ I.O. Kresina, O. V. Kresin, Getman Pylyp Orlyk I yogo konstytuciya, Kyiv 1993, pp. 45-62. 
struggle of Slavic peoples against foreign oppression, as a result of the "Spring of Nations", i.e. the bourgeois-democratic revolutions in 1848-1849, and the abolition of serfdom in the Russian Empire in 1861.

Yet in the early $19^{\text {th }}$ century, in Ukraine enslaved by the Russian Empire, there was no way to revive the structures of civil society. These conditions were kept only in the western part of Ukraine, which after the collapse of the Commonwealth of Poland and Lithuania in the late $18^{\text {th }}$ century became part of Austria, and since 1868 part of the Austro-Hungarian Empire.

It was in this part of Ukraine that conditions for the formation of civil society appeared in the $19^{\text {th }}$ century. This was due to several reasons, especially because of the policy of enlightened absolutinsm of the Austrian monarchs, including Maria Theresa and her son Joseph II, subordinated to the formation of responsible citizens of the empire as an effective factor of its power. Another cause was the steady consolidation of the bourgeois-democratic principles across Western European countries, primarily following the revolutionary events in 1848-1849, the so-called Spring of Nations ${ }^{32}$.

In Western Ukraine, it had exceptional social, economic and political importance, contributing to Galician Ukrainian national revival, stimulating the formation of a new elite with its program of action oriented towards the national liberation.

In 1781-1782, emperor Joseph II freed the peasants from personal dependence on landlords, limited serfdom, forbade landlords to increase their ownerships at the expense of peasants' land. On April 16 ${ }^{\text {th }}, 1848$ the Austrian emperor finally abolished serfdom. Under the agrarian reform, state bought peasant land from the landlords for future recovery lasting over 40 years. As a result of reforms, over 375,000 free farms were created in Eastern Galicia which, in fact, were the backbone of the middle class, and thus the founders of civil society ${ }^{33}$.

Church reformation as well contributed to the democratization of society by equalizing the rights of Greek-Catholic church with the Catholic and Protestant clergy. Furthermore, studying at Ukrainian universities and serving in a civil service was henceforth permitted. A Greek Catholic Seminaries were founded in Vienna, L'viv and Uzhgorod to train clergy who were the heart of the Ukrainian elite, taking an active part in public life, particularly in

\footnotetext{
${ }^{32}$ Y. Grytsak, Narys istorii Ukrainy. Formuvannya ukrainskoyi modernoyi nacii XIX-XX stolittya, Kyiv 2000, pp. 41-45.

${ }^{33}$ M.V. Lazarovych, Istoria Ukrainy, pp. 259-260.
} 
the creation and activities of cultural and educational societies and organizations.

Educational reform created primary and secondary schools. Moreover, elementary education was conducted in the native language, which was an important prerequisite for the growth of various sectors of social activity in Galicia, especially among the peasantry.

Creation of the Supreme Ruthenian Council in L'viv on May $2^{\text {nd }}, 1848$, offers striking evidence of increasing social and national maturity of Ukrainian Galicia It was the first political organization that issued a number of democratic requirements to the imperial government in Vienna, including the division of Galicia into two separate administrative units - the Eastern dominated by Ukrainians and the Western, inhabited mainly by Poles. In addition, the program of the Supreme Ruthenian Council proclaimed unity of the Ukrainian people and its right to restore independence. It established more than 50 local councils from different segments of the population. It should also be noted that the Supreme Ruthenian Council established a cultural and educational society Galician-Ruthenian Matica, which published school textbooks, organized youth education in their mother language ${ }^{34}$.

On October $20^{\text {th }}, 1860$, under the new Constitution, Galicia gained autonomy with its own Seim and Provincial Government. Galician Seim consisted of 150 ambassadors. Following the first elections, Ukrainians had 49 representatives. In addition, during the democratisation of administration in some provinces of Austria in 1861 along with state and administrative structures, self-governing bodies were formed : the Seim and county assemblies called sejmyky .

Later, due to increased social and national maturity and political activity of the Ukrainian community of Galicia many NGOs appeared. There were organisations concerned with economic activity and providing financial structures, such as Sil'ski hospodar, Narodna Torhivlia, bank Dniester, The Regional Credit Union, Regional Audit union, Union of Milk Unions; cultural and educational bodies - Europihijski Institute, Prosvita, Ridna Shkola, Ruthenian Pedagogical Society, Taras Shevchenko Scientific Society; youth and sports organizations - Plast, Sokil, Sokil-Batko, Kameniari and others ${ }^{36}$.

\footnotetext{
${ }^{34}$ Ibidem, pp. 260-266.

${ }^{35}$ S.A. Makarchuk, Dzhereloznavstvo istorii Ukrainy, Lviv 2008, pp. 177-181.

${ }^{36} \mathrm{~B}$. Trofymiak, Gimnastychno-sportyvni organizaciyi v nacionalno-vyzvolnomu rusi Galychyn, Ternopil 2001, pp. 47-54.
} 
In the late $19^{\text {th }}$ and early $20^{\text {th }}$ century, there appeared political parties and organizations which took on the burden of leadership of the national liberation struggle for independence and unity of Ukraine.

The conceptual nature of non-governmental activities in Western Ukraine was to become an ethno-cultural alternative to occupants. In the conditions of statelessness, Galician Ukrainian organizations tried to take over some state functions to cater better to the needs for essential public service and, through hard work, to nurture national consciousness, to consolidate national power and thus "prepare them by way of evolution for the struggle for liberation and greatly to the revival of the modern state" 37 .

\section{Tatiana Panfilova \\ TWORZENIE I FUNKCJONOWANIE SPOŁECZEŃSTWA OBYWATELSKIEGO NA UKRAINIE OD II POL. XVI DO XIX WIEKU}

\section{Streszczenie}

$\mathrm{Na}$ podstawie źródeł i historiografii została odtworzona specyfika tworzenia struktur ukraińskiego społeczeństwa obywatelskiego - jako czynnik tworzenia ukraińskiej idei narodowej.

W zależności od czasu, warunków, pochodzenia i przedsiębiorczości, a tym samym poziomu społeczno-gospodarczego i dojrzałości politycznej społeczeństwa na pewnym etapie jego rozwoju, politolodzy zdefiniowali istotę społeczeństwa obywatelskiego. Odzwierciedla ono zbiór relacji, które nie są polityczne, ale odnoszą się do samorządu terytorialnego, różnych stowarzyszeń gospodarczych, społecznych, politycznych, narodowych, kulturowych i religijnych, które działają autonomicznie względem państwa i są najczęściej poza granicami polityki i regulacji.

Pod koniec XIX i na początku XX wieku różne partie i organizacje wzięły na siebie ciężar przewodzenia narodowo-wyzwoleńczej walce o niepodległość i samostanowienie Ukrainy.

Ideą organizacji pozarządowych w Zachodniej Ukrainie było ustanowienie etnokulturowej alternatywy wobec reżymu okupacyjnego. W czasie bezpaństwowości galicyjskiej ludności ukraińskiej organizacje te starały się przejąć na siebie część funkcji państwowych dla zabezpieczenia potrzeb w podstawowych sferach społec-

\footnotetext{
${ }^{37}$ B. Savchuk, Prosvitnytska ta socialno-ekonomichna diyalnist ukrainskych gromadskych tovarystv u Galychyni (ostannya tretyna XIX st. - kinets 30-h rokiv XX st.), Ivano-Frankivsk 1999, pp. 118-120.
} 
znych - pracy, wychowywania, budowania świadomości narodowej, konsolidowania sił narodowych i tym samym „ewolucyjnego przygotowania ich do walki o wyzwolenie i w dużej mierze do nowego społecznego odrodzenia”.

\section{Bibliography}

Chuhlib T., Getmany i monarchy. Ukrainska derzhava v mizhnadordnych vidnosynach 1648-1714 , Kyiv 2003.

Chuhlib T., Secrety ukrainskogo polivasalitetu: Khmelnytskyy - Doroshenko - Mazepa, Kyiv 2011.

Dzyra Y., Persyi passport kozatstva. Naydavnishyi reestr Nyzovogo viyska. 1581, Literaturna Ukraina 1991, July 13, p. 5-6.

Grytsak Y., Narys istorii Ukrainy. Formuvannya ukrainskoyi modernoyi nacii XIX-XX stolittya, Kyiv 2000.

Ioann Mazepa, Vozhd viyska Zaporizkogo, oboh chasten Borystena, slavnogo ordena svyatogo Apostola Andrija, bologo orla Kavaler, Den' 43-44, 12-13 March 2010, p. 6-8.

Istoria Ukrainy vid naydavnishyh chasiv do siogodennya. Zbirnyk dokumentiv I materialiv, Kyiv-Chernivtsi 2008.

Knyazev V., Kanak F., Derzhava i gromadyanske suspilstvo: evotutsia stosunkiv ta yih osmyslennya, [in:] Formuvannya gromadyanskogo suspilstva v Ukraini: stan, problemy, perspectyvy: Collection of scientific works of the Ukrainian Academy of Public Administration Under the President of Ukraine, Kyiv 2001, p. 252.

Kresina I.O., Kresin O.V., Getman Pylyp Orlyk I yogo konstytuciya, Kyiv 1993.

Krypyakevych I., Istoria Ukrainy, Lviv 1990.

Lazarovych M.V., Istoria Ukrainy, Kyiv 2008.

Lypynskyy V., Religia i cerkva v istorii Ukrainy, New York 1956.

Makarchuk S.A., Dzhereloznavstvo istorii Ukrainy, Lviv 2008.

Polonska-Vasylenko N., Istoria Ukrainy, II, Vid polovyny 16. storichcha do 1923 roku, München 1976.

Pryvileji mista Lvova: 16. st., Lviv 1998.

Savchuk B., Prosvitnytska ta socialno-ekonomichna diyalnist ukrainskych gromadskych tovarystv u Galychyni (ostannya tretyna XIX st. - kinets 30-h rokiv XX st.), Ivano-Frankivsk 1999.

Shevchuk V., Nacionalna idea v Ukraini, zokrema nacionalno-vyzvolna, ta yiyi podvyzhnyky, Kyiv 2007.

Smoliy V., Stepankov V., Petro Doroshenko. Politychnyy portret, Kyiv 2011.

Smoliy V., Stepankov V., Ukrainska natsionalna revolutsia XVII st. (1648-1676), Kyiv 2009.

Trofymiak B., Gimnastychno-sportyvni organizaciyi v nacionalno-vyzvolnomu rusi Galychyn, Ternopil 2001. 